\title{
Eger Rift ICDP: an observatory for study of non-volcanic, mid-crustal earthquake swarms and accompanying phenomena
}

\author{
T. Dahm ${ }^{1,6}$, P. Hrubcová ${ }^{2}$, T. Fischer ${ }^{3}$, J. Horálek ${ }^{2}$, M. Korn ${ }^{5}$, S. Buske ${ }^{4}$, and D. Wagner ${ }^{1,6}$ \\ ${ }^{1}$ GFZ German Research Centre for Geosciences, Telegrafenberg, 14473 Potsdam, Germany \\ ${ }^{2}$ Institute of Geophysics, Academy of Science, 14131 Prague, Czech Republic \\ ${ }^{3}$ Faculty of Science, Charles University in Prague, Albertov 6, 128 43, Prague, Czech Republic \\ ${ }^{4}$ Institute of Geophysics and Geoinformatics, TU Bergakademie Freiberg, 09599 Freiberg, Germany \\ ${ }^{5}$ Institut für Geophysik und Geologie, Universität Leipzig, Talstraße 35, 04103 Leipzig, Germany \\ ${ }^{6}$ Institute of Earth and Environmental Sciences, University of Potsdam, \\ Karl-Liebknecht-Str. 24, 14476 Golm, Germany
}

Correspondence to: T. Dahm (torsten.dahm@gfz-potsdam.de) and P. Hrubcová (pavla@ig.cas.cz)

Received: 30 July 2013 - Revised: 3 October 2013 - Accepted: 11 October 2013 - Published: 5 November 2013

\section{Introduction and goals}

What are the physical and chemical processes leading to earthquakes and volcanic eruptions? How does fluid transfer through the earth's crust work? How may geological processes influence the deep biosphere and the evolution of early life at depth? These are questions tackled by the ICDP project and the planned drilling in the Eger Rift region. For several centuries, the West Bohemia (Czech Republic) and the Vogtland regions (Germany) have faced earthquake swarm seismicity and large-scale diffuse degassing of mantle-derived $\mathrm{CO}_{2}$ (e.g. Horálek and Fischer, 2008). The scientific term "earthquake swarm" (ES) was coined in this area following the 1824 Hartenberg (Vogtland) earthquakes in order to describe the intensive, long-lasting, low-magnitude seismicity felt by the population (Knett, 1899). Since then, earthquake swarms have been recognized in many regions worldwide under different tectonic and volcanic settings. Their mechanism, however, is still enigmatic and not understood. Recently, the potential hazard posed by earthquake swarms was demonstrated during the destructive $M_{\mathrm{W}} 6$ Aquila 2009 earthquake (Italy), which was preceded by three months of earthquake swarms. Nowadays, it is well accepted that ES are driven by fluid instability in the crust. These may be magmatic fluids for ES at volcanoes, or cold/meteoric fluids for ES in other regions, or mantle-derived fluids passing the brittle-ductile barrier through deep rooting faults (e.g. Becken et al., 2011). In West Bohemia-Vogtland, it is still unknown whether magma, water, $\mathrm{CO}_{2}$ or other mantlederived fluids are driving the persistent ES activity at midcrustal levels at several locations over an area of about $40 \mathrm{~km}$ $\times 60 \mathrm{~km}$ (Fig. 1). This geographical region is also characterized by numerous mineral springs, Tertiary-Quaternary volcanism and neotectonic crustal movements, and is located at the intersection of two major intraplate fault zones. It is likely that all these phenomena are related to a common origin.

The area is prone to massive $\mathrm{CO}_{2}$ degassing that occurs in the form of $\mathrm{CO}_{2}$-rich mineral waters and wet and dry mofettes in several degassing fields along tectonic fault zones. The gases have high ${ }^{3} \mathrm{He} /{ }^{4} \mathrm{He}$ ratios significantly higher than average continental crust, which is a characteristic indicating their origin deep in the mantle. The long-term degassing of $\mathrm{CO}_{2}$ in granitic and sedimentary layers makes this area ideally suited to study the effect of $\mathrm{CO}_{2}$ on the deep biosphere and the development of life at depth.

The ICDP Eger Rift Project aims to develop the most modern, comprehensive observatory worldwide for the study of ES and $\mathrm{CO}_{2}$ degassing in order to reach a new level of high frequency, near-source, and multi-parameter observation of ES and related phenomena. Such a laboratory will comprise a network of a high frequency 3-D seismic arrays with a set of five to six shallow boreholes. This report summarizes the outcome of the 2nd Eger Rift Workshop held during 4-5 June 2013 in Potsdam, Germany. 
(a)

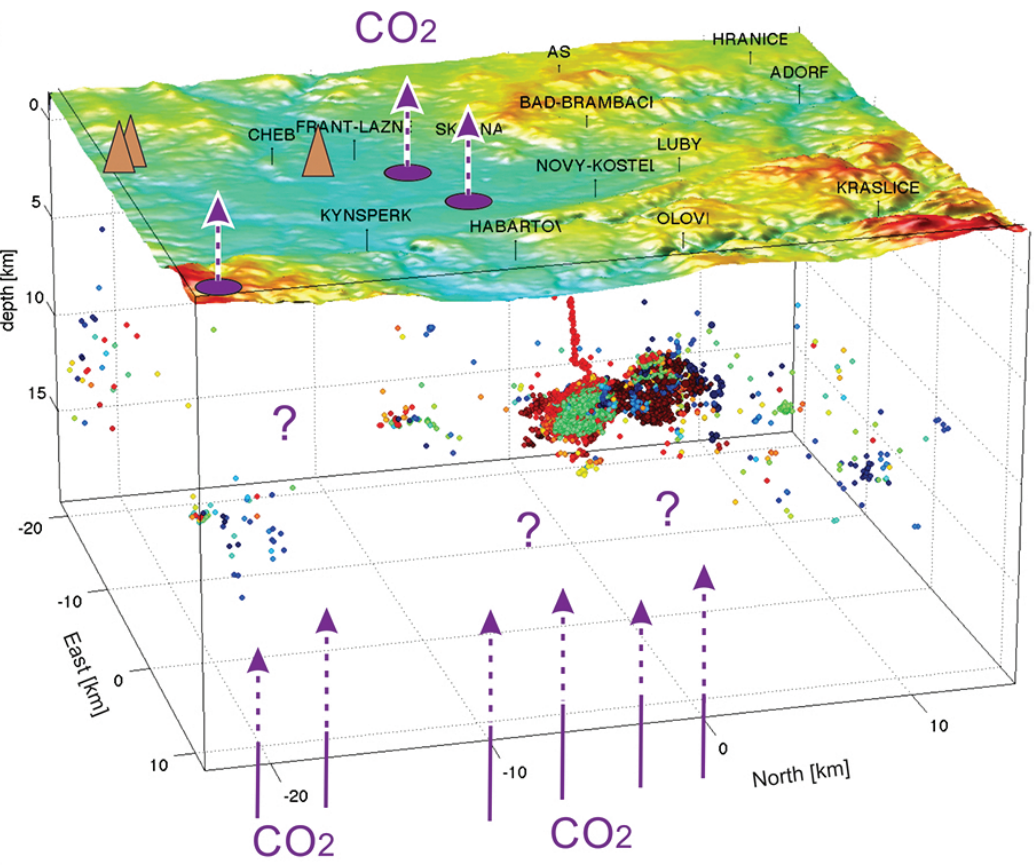

(b)

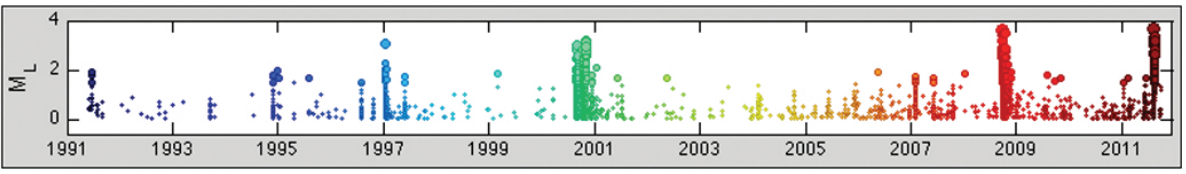

Figure 1. (a) Perspective 3-D view of the central earthquake swarm region in West Bohemia-Vogtland. Hypocenters are indicated by filled circles, the magnitudes and time of occurrence is plotted in (b) Topography is indicated as coloured map and ranges between 400 and $800 \mathrm{~m}$. Violet arrows sketch the possible $\mathrm{CO}_{2}$ migration paths (diffuse or in channels). Mofettes indicated by violet ellipses; brown triangles mark known Quaternary volcanoes. See Fig. 3 for location in Central Europe.

\section{Earthquake swarms and $\mathrm{CO}_{2}$ degassing in West Bohemia-Vogtland}

Earthquake swarms are usually considered as sequences of numerous small events at shallow depths which cluster in time and space. The few dominant earthquakes do not have similar magnitudes, so smaller events are not associated with any identifiable main shock. This was formerly explained as a consequence of a very heterogeneous stress field and weakened crust, which lacks a single well-developed fault and is incapable of sustaining higher strain (Mogi, 1963). However, nowadays ES are typically interpreted as a consequence of fast fluid movement at depth and the triggering by fluid-induced effective stress. Earthquake swarms often occur in volcanic areas or at geothermal fields (e.g. Dahm and Brandsdottir, 1997; Wyss et al., 1997; Lees, 1998; Dreger et al., 2000; McNutt, 2005). Intraplate earthquake swarms in regions without active volcanism have been reported, for example, at continental rifts like Rio Grande, Kenya, and West Bohemia (Ibs-von Seht et al., 2008).

The first references of earthquake observations in West Bohemia-Vogtland date back to medieval times, however, macroseismically they have been documented since the be- ginning of the 19th century. Many swarms occurred with the largest equivalent local magnitudes not exceeding $M_{\mathrm{L}} 5$ (e.g. 1875 or 1908). To date, the largest instrumentally recorded earthquake occurred in the 1985-1986 swarm and reached the magnitude of $M_{\mathrm{L}} 4.6$ (Vavryčuk, 1993). The seismicity is generally shallow, with the event hypocentres occurring in the upper and middle crust mainly between 5 and $15 \mathrm{~km}$ (Fischer and Horálek, 2003).

At present, the highest concentration of earthquake activity and $\mathrm{CO}_{2}$ degassing occurs in the area of the Cheb Basin, with three Quaternary active volcanoes and the intersection of the Eger Rift and the Regensburg-Leipzig-Rostock Zone (Bankwitz et al., 2003; and Fig. 1). It seems that the earthquake swarms are related to the re-activation of a complex system of faults, at least for the Nový Kostel swarm area. Since 1997, about $80 \%$ of the regional seismic energy has been released beneath Nový Kostel (Fischer and Michálek, 2008). The hypocentres cluster at depths from 6 to $13 \mathrm{~km}$ along a steeply dipping fault plane with complicated geometry (Fig. 2). The earthquake swarms show a strongly episodic character and migrating hypocentres with the reactivation of previously ruptured parts on a single fault. Detailed studies of the recent ES at Nový Kostel revealed the 


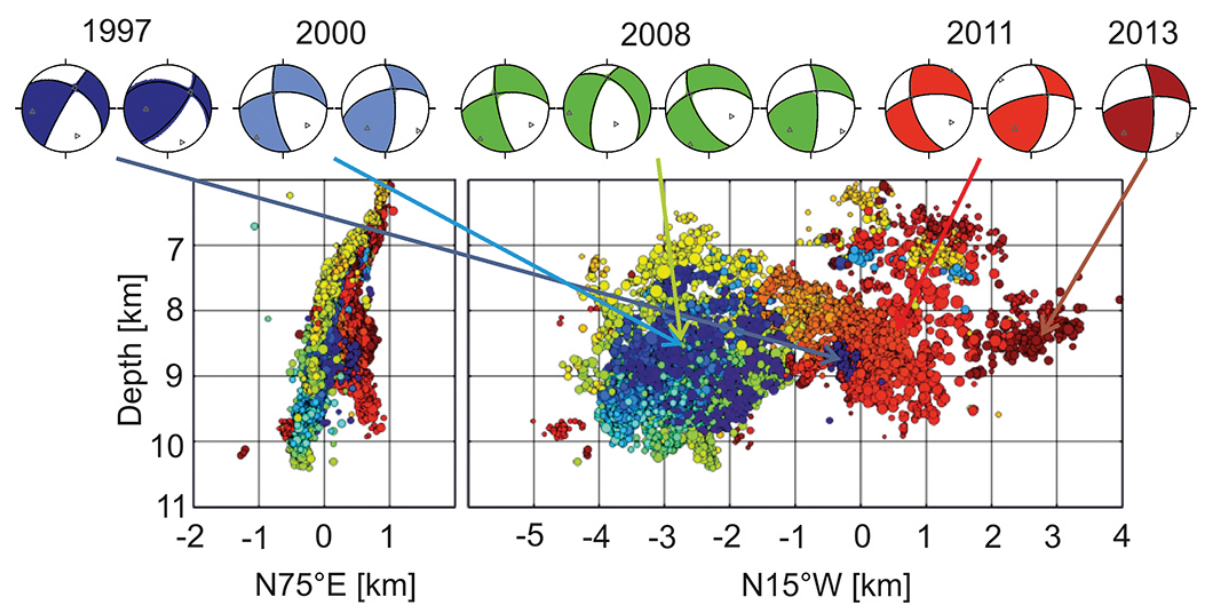

Figure 2. Two perpendicular profile depth sections of the Nový Kostel swarm hypocenters (circles) of swarms 1997 (dark blue), 2000 (blue), 2008 (yellow-green), 2011 (orange-red) and 2013 (dark red). Typical focal solutions are selected for the major swarms. Events are plotted for magnitude larger than 0.5 ; circle size refers to magnitude. The largest recorded event with magnitude $M_{\mathrm{L}} 3.8$ occurred in the swarm 2008 .

occurrence of clear volumetric and non-double couple source components in the radiation pattern of individual earthquakes (Dahm et al., 2000; Vavryčuk, 2011; Horálek and Š́lený, 2013; Vavryčuk et al., 2013). Evidence of volumetric source components is a rare observation worldwide and indicates that faults at depth are under very high fluid overpressure exceeding the minimum principle stress (see also Hainzl et al., 2012; Dahm et al., 2008), which influences the rupture mechanism of micro-earthquakes by means of simultaneous shear-tensile dislocation (e.g. Vavryčuk, 2011). Otherwise, the stress field inverted from the focal mechanisms is consistent with that of Western Europe.

According to carbon isotopic studies, the $\mathrm{CO}_{2}$ in mineral springs and mofettes of the region originate from the upper mantle (Weinlich et al., 1999; Bräuer et al., 2004). Three degassing centres are supplied by magmatic fluids from magma reservoirs at Moho depths (Bräuer et al., 2008 and Fig. 1). In the Cheb Basin, the portion of mantle-derived helium is the highest and the subcontinental helium isotopic signature indicates fluid transport from the deep lithospheric mantle. The progressive temporal increase in the mantle-helium level may indicate a connection among faults in the deeper crust (Bräuer et al., 2009, 2011). The observed pre-seismic decrease of ${ }^{3} \mathrm{He} /{ }^{4} \mathrm{He}$ ratios, simultaneous increase of the $\mathrm{CO}_{2}$ emissions and groundwater level changes are interpreted as strain changes in the rocks associated with the preparatory phase of earthquake swarms (Bräuer et al., 2007).

\section{Tectonic, volcanic, and structural setting}

The Bohemian Massif, one of the largest stable outcrops of pre-Permian rocks in Central and Western Europe, creates the easternmost part of the Variscan orogenic belt and developed approximately between 500 and $250 \mathrm{Ma}$ during a period of large-scale crustal convergence, the collision of continental plates and microplates, and subduction (Matte et al., 1990). West Bohemia is situated in the transition zone among three different Variscan structural units of the Bohemian Massif (Fig. 3). The post-orogenic extension, together with the alkaline magmatic activity during the Cenozoic led to the evolution of the Eger Rift. The Eger Rift is a $300 \mathrm{~km}$ long and $50 \mathrm{~km}$ wide zone trending ENE-WSW and is an active element of the European Cenozoic Rift System (Prodehl et al., 1995; and Fig. 2). The sedimentary fill of the Cheb Basin consists of Tertiary and Quaternary sediments up to $300 \mathrm{~m}$ thick and represents debris of the surrounding magmatic and metamorphic rocks. The tectono-sedimentary structure is associated with a system of Cenozoic sedimentary basins in West Europe and intense intraplate alkaline volcanism (Ulrych et al., 2011). The Quaternary volcanism is documented in at the flanks of the Eger Rift (Proft, 1894; Seifert and Kämpf, 1994; Geissler et al., 2004; Mrlina et al., 2009; and Fig. 1).

The main earthquake swarm area is located at the intersection of two tectonic structures, the ENE-WSW striking Eger Rift and the NNW-SSE striking Mariánské Lázně Fault with the Tertiary Cheb Basin in the centre. The Mariánské Lázně Fault intersects the area close to the main seismo-active zone of Nový Kostel. The position of the Cheb Basin may be controlled by a N-S striking seismo-tectonic structure, the so-called Regensburg-Leipzig-Rostock Zone (Bankwitz et al., 2003).

The crustal and upper mantle structure was previously investigated in several active seismic experiments and passive monitoring (DEKORP Research Group, 1994; Behr et al., 1994; Tomek et al., 1997; Enderle et al., 1998; Hrubcová et al., 2005; Hrubcová and Geissler, 2009; Brúckl et al., 2007; Grad et al., 2008). Passive seismic experiments were carried out to study major lithospheric discontinuities using the receiver function approach (Geissler et al., 2005; Heuer et al., 


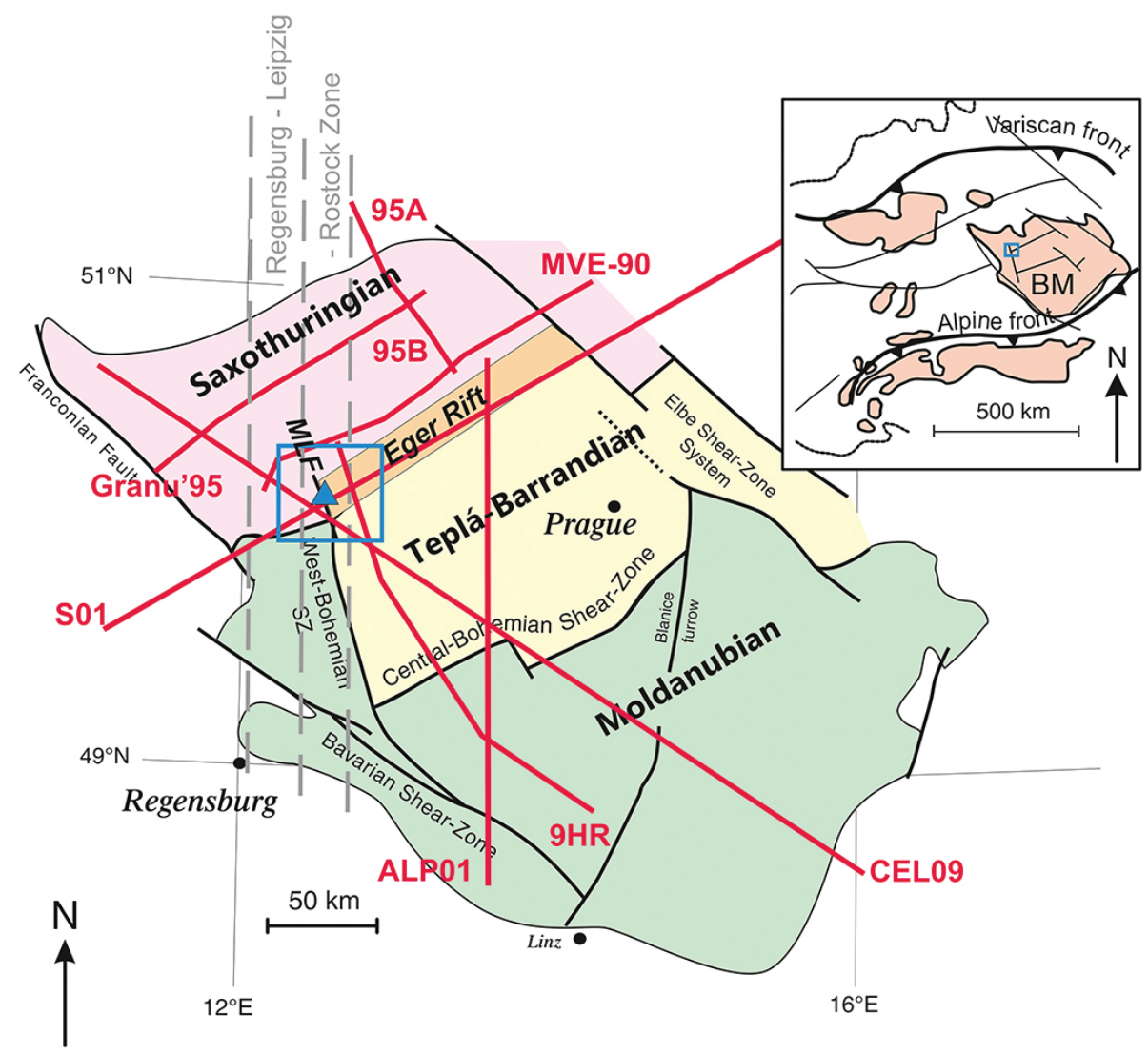

Figure 3. Tectonic-geological setting (after Pitra et al., 1999) indicating major regional tectonic units and shear zones within the Bohemian Massif (BM). The main focal zone at Nový Kostel (see Fig. 1) is indicated by the blue triangle; blue squares refer to area plotted in Fig. 1. Seismic wide angle profiles are indicated by red lines. MLF: Mariánské Lázně Fault.

2006). These investigations exhibited complex crustal structure with a wide zone of increased reflectivity at the crustmantle transition, confirmed by Hrubcová et al. (2013). According to Geissler et al. (2005), these lower crustal features may be interpreted as low-angle shear zones partly filled with fluids and/or small magmatic intrusions or partial melting as confirmed by mantle xenoliths. Furthermore, recent reprocessing of seismic reflection data revealed an improved structural image of the crust and upper mantle, in particular very distinct and highly reflective features ("bright spots") in the upper crust which can be directly related to the spatiotemporal behaviour of the swarm activity and their fluiddriven origin (Klemt, 2013; Mullick et al., 2013; Schimschal, 2013).

\section{Geomicrobiology and early life in deep subsurface geo-ecosystems of the Eger Rift}

Microbiological studies over the last two decades have shown the existence of diverse and active microbial ecosystems in the deep subsurface (Parkes et al., 2000; Pederson, 2000; Lehman, 2007). Previous studies (Whitman et al., 1998) estimated that between $75 \%$ and $94 \%$ of all microbes on earth occur in deeply buried marine and terrestrial sediments, representing the second-largest pool of living biomass after land plants. Despite recent advances in microbiological deep subsurface exploration, deep terrestrial environments remain relatively unexplored; mainly due to difficulties in obtaining suitable samples. While microbiological research is already part of the "International Ocean Discovery Program" (IODP) (Parkes et al., 1994; D’Hondt et al., 2007) only a few recent projects within the ICDP have had a microbiological component (Colwell et al., 2005; Gohn et al., 2008; Glombitza et al., 2013; Vuillemin and Ariztegui, 2013).

The Eger Rift represents an excellent opportunity to extend our knowledge about microbial life in the terrestrial subsurface. The area hosts a diverse lithology of surficial sediments overlying crystalline rocks as well as active $\mathrm{CO}_{2}$ degassing and high flow rates of mineral-rich fluids, thereby allowing for the study of many different phenomena. Key research topics would be the development of microbial life in tectonic faults and changes in microbial community composition and metabolic activity in response to changing lithology. It was furthermore hypothesized that deep-reaching tectonic faults in geological active regions like the Eger Rift may provide possible reaction habitats for the formation of 
prebiotic molecules and the development of early life on the earth (Bräuer et al., 2005; Schreiber et al., 2012).

\section{Workshop results}

The main goal of the 2nd ICDP Eger Rift Workshop was to discuss a conceptual drilling approach to address the key scientific questions related to the swarm processes. During the meeting, 50 scientists from Germany, Czech Republic, USA, UK, and Poland discussed up-to-date scientific knowledge and plans for drilling in this area during overviews, keynote lectures, and short presentations. Three scientific groups were identified based on their interests in the area: a seismological group, a group interested in tectonics and volcanology/petrology issues, and a paleoclimate/geomicrobiology group. Group discussions concentrated on scientific relevance of the proposed research plans, societal and potential outreach issues, specific requirements for drilling, expected results, and collaborations among groups within the international context, as well as potential funding.

The workshop participants discussed possibilities of deep drilling together with a network of shallow boreholes. They concluded that a better understanding of the earthquake swarm processes and fluid interactions are the key problems. Since a deep drilling cannot reach the seismogenic zone, such problems can be addressed by the planned observatory. This will include questions about whether the earthquakes are fluid driven, the relation of fluids to near-surface mineral water resources, and potential seismic and volcanic hazards in the spa area. Another line of relevance concerns the sustainability of mineral water and hot springs resources, or better quantification of the geothermal potential. The planned observatory will bring a third dimension into the investigation that will improve our knowledge of source parameters, weak earthquakes detection and fluid driven mechanisms. The boreholes will also improve fluid mobility monitoring due to filtration of $\mathrm{CO}_{2}$ meteorological effects and biosphere monitoring of deep subsurface geo-ecosystems of early life on the earth.

These questions can be addressed by taking a step up from the current short-period seismic monitoring network to a high frequency 3-D seismic array. A set of five to six shallow boreholes ( $\sim 500 \mathrm{~m}$ deep) should be equipped with vertical seismic arrays and combined with surface small-aperture high frequency arrays. Such a configuration will allow the study of source and rupturing processes up to $100 \mathrm{~Hz}$ and down to the magnitudes of -2 . The boreholes of this novel array of 3-D arrays can additionally be used to close azimuthal and take-off angle gaps in the current monitoring network, to include high precision deformation measurements from boreholes (tilt- and strainmeters), to set up a deep monitoring of $\mathrm{CO}_{2}$ degassing free of the effect of surface environmental parameter variations and allow for heat flow measurements and self-potential monitoring. Reflection seismic-site characteri- zation works around these boreholes as well as such that target the main fault plane of the swarms are mandatory in that respect in order to relate the phenomena observed in the boreholes to the large-scale structure and process of fluid flow in the crust.

These plans will lead to studies of mid-crustal and shallow fluid-rock interaction, the physical and chemical processes for the earthquake swarms, the associated seismic and volcanic hazard, as well as the intra-continental $\mathrm{CO}_{2}$ flux and fluid transfer through the complete crustal layer. Drilling and coring as well as observations will additionally serve to study the nature of the deep biosphere, petrologic processes, and paleoclimatic issues connected with the massive $\mathrm{CO}_{2}$ degassing and the existence of Tertiary and Quaternary volcanoes within shallow basin structures.

The workshop resulted in a plan to address the above mentioned issues through 5-6 boreholes approximately $500 \mathrm{~m}$ deep in a distance up to 15 or $20 \mathrm{~km}$ from the main Nový Kostel seismic zone. Two of the boreholes will be located in Vogtland, four in West Bohemia. The precise sites for drilling will be selected with regards to the results of a new high-resolution reflection seismic profile crossing the Nový Kostel fault zone. Sites in the sedimentary successions of the Cheb Basin will be selected at places that also cover documented $\mathrm{CO}_{2}$ degassing along a nearby fault zone, as required for gas/chemical and tectonic/petrologic investigations. Boreholes in sedimentary structures will be utilized for volcanological and paleoclimate research while microbiological investigations will centre around sampling of fault structures affected by long-lasting degassing and where microbes most likely have developed during the past.

Acknowledgements. We thank all the participants of the workshop, who contributed to preparation of this report. We want to thank Uli Harms and Roland Oberhänsli and the German Science Foundation, who supported this workshop.

Edited by: U. Harms

Reviewed by: T. Wiersberg and M. J. Jurado

\section{References}

Babuška, V., Plomerová, J., and Fischer, T.: Intraplate seismicity in the western Bohemian Massif (central Europe): a possible correlation with a paleoplate junction, J. Geodyn., 44, 149-159, 2007.

Bankwitz, P., Schneider, G., Kämpf, H., and Bankwitz, E.: Structural characteristics of epicentral areas in Central Europe: study case Cheb Basin (Czech Republic), J. Geodyn., 35, 5-32, doi:10.1016/S0264-3707(02)00051-0, 2003.

Becken, M., Ritter, O., Bedrosian, P. A., and Weckmann, U.: Correlation between deep fluids, tremor and creep along the central San Andreas fault, Nature, 480, 87-90, doi:10.1038/nature10609, 2011.

Behr, H. J., Dürbaum, H. J., and Bankwitz, P.: Crustal structure of the Saxothuringian Zone: Results of the deep seismic profile MVE-90 (East), Z. Geol. Wiss., 22, 647-769, 1994. 
Bräuer, K., Kämpf, H., Niedermann, S., Strauch, G., and Weise, S. M.: Evidence for a nitrogen flux directly derived from the European subcontinental mantle in the Western Eger Rift, central Europe, Geochim. Cosmochim. Ac., 68, 4935-4937, 2004.

Bräuer, K., Kämpf, H., Faber, E., Koch, U., Nitzsche, H.-M., and Strauch, G.: Seismically triggered microbial methane production relating to the Vogtland - NW Bohemia earthquake swarm period 2000, Central Europe, Geochem. J., 39, 441-450, 2005.

Bräuer, K., Kämpf, H., Koch, U., Niedermann, S., and Strauch, G.: Seismically-induced changes of the fluid signature detected by a multi-isotope approach $\left(\mathrm{He}, \mathrm{CO}_{2}, \mathrm{CH}_{4}, \mathrm{~N}_{2}\right)$ at the "Wettinquelle", Bad Brambach (Central Europe), J. Geophys. Res., 112, B04307, doi:10.1029/2006JB004404, 2007.

Bräuer, K., Kämpf, H., Niedermann, S., Strauch, G., and Tesař, J.: The natural laboratory NW Bohemia - Comprehensive fluid studies between 1992 and 2005 used to trace geodynamic processes, Geochem. Geophy. Geosy., 9, Q04018, doi:10.1029/2007GC001921, 2008.

Bräuer, K., Kämpf, H., and Strauch, G.: Earthquake swarms in nonvolcanic regions: What fluids have to say, Geophys. Res. Lett., 36, L17309, doi:10.1029/2009GL039615, 2009.

Bräuer, K., Kämpf, H., Koch, U., and Strauch, G.: Monthly monitoring of gas and isotope compositions in the free gas phase at degassing locations close to the Nový Kostel focal zone in the western Eger Rift, Czech Republic, Chem. Geol., 290, 163-176, doi:10.1016/j.chemgeo.2011.09.012, 2011.

Brúckl, E., Bleibinhaus, F., Gosar, A., Grad, M., Guterch, M., Hrubcová, P., Keller, G. R., Majdański, M., Sumanovac, F., Tiira, T., Yliniemi, J., Hegedús, E., and Thybo, H.: Crustal structure due to collisional and escape tectonics in the Eastern Alps region based on profiles Alp01 and Alp02 from the ALP 2002 seismic experiment, J. Geophys. Res., 112, B06308, doi:10.1029/2006JB004687, 2007.

Colwell, F. S., Nunoura, T., Delwiche, M. E., Boyd, S., Bolton, R., Reed, D. W., Takai, K., Lehman, R. M., Horikoshi, K., Elias, D. A., and Phelps, T. J.: Evidence of minimal methanogenic numbers and activities in sediments collected from JAPEX/JNOC/GSC et al. Mallik 5L-38 gas hydrate production research well, in: Scientific Results from the Mallik 2002 Gas Hydrate Production Research Well Program, Mackenzie Delta, Northwest Territories, Canada, Geological Survey of Canada, Bulletin, edited by: Dallimore, S. R. and Collett, T. S., 585, 1-11, 2005.

Dahm, T. and Brandsdottir, B.: Moment tensors of microearthquakes from the Eyjafjallajökull volcano in South Iceland, Geophys. J. Int., 130, 183-192, 1997.

Dahm, T., Š́lený, J., and Horálek, J.: Comparison of moment tensor solutions for the January 1997 West Bohemia earthquake swarm. Stud, Geoph. et Geod., 44, 233-250, 2000.

Dahm, T., Fischer, T., and Hainzl, S.: Mechanical intrusion models and their implications for the possibility of magma-driven swarms in NW Bohemia region, Stud. Geophys. Geod., 52, 529_ 548, 2008

DEKORP Research Group: The deep reflection seismic profiles DEKORP 3/MVE-90, Z. Geol. Wiss., 22, 623-824, 1994.

D'Hondt, S. L., Inagaki, F., Ferdelman, T., Joergensen, B. B., Kato, K., Kemp, P., Sobecky, P., Sogin, M. L., and Takai, K.: Exploring Subseafloor Life with the Integrated Ocean Drilling Program, Scientific Drilling, 5, 26-37, 2007.
Dreger, D. S., Tkalcic, H., and Jonston, M.: Dilational processes accompanying earthquakes in the Long Valley Caldera, Science, 288, 122-125, 2000.

Enderle, U., Schuster, K., Prodehl, C., Schultze, A., and Briebach, J.: The refraction seismic experiment GRANU'95 in the Saxothuringian belt, southeastern Germany, Geophys. J. Int., 133, 245-259, 1998.

Fischer, T. and Horálek, J.: Space-time distribution of earthquake swarms in the principal focal zone of the NW Bohemia/Vogtland seismoactive region?, J. Geodyn., 35, 125-144, 2003.

Fischer, T. and Michálek, J.: Post 2000-swarm microearthquake activity in the principal focal zone of West Bohemia/ Vogtland: space-time distribution and waveform similarity analysis, Stud. Geophys. Geod., 52, 493-511, 2008.

Geissler, W. H., Kämpf, H., Bankwitz, P., and Bankwitz, E.: The Quaternary tephra-tuff deposit of Mýtina (southern rim of the western Eger Graben/Czech Republic): Indications for eruption and deformation processesn, Z. Geol. Wiss., 32, 31-54, 2004 (in German with summary in English).

Geissler, W. H., Kämpf, H., Kind, R., Klinge, K., Plenefisch, T., Horálek, J., Zedník, J., and Nehybka, V.: Seismic structure and location of a $\mathrm{CO}_{2}$ source in the upper mantle of the western Eger rift, Central Europe, Tectonics, 24, TC5001, doi:10.10292004TC001672, 2005.

Glombitza, C., Stockhecke, M., Schubert, C. J., Vetter, A., and Kallmeyer, J.: Sulfate reduction controlled by organic matter availability in deep sediment cores from the saline, alkaline Lake Van (Eastern Anatolia, Turkey), Frontiers in Microbiology, doi:10.3389/fmicb.2013.00209, in press, 2013.

Gohn, G. S., Koeberl, C., Miller, K. G., Reimold, W. U., Browning, J. V., Cockell, C. S., Horton, J. W., Kenkmann, T., Kulpecz, A. A., Powars, D. S., Sanford, W. E., and Voytek, M. A.: Deep drilling into the Chesapeake Bay impact structure, Science, 320, 1740-1745, 2008.

Grad, M., Guterch, A., Mazur, S., Keller, G. R., Špičák, A., Hrubcová, P., and Geissler, W. H.: Lithospheric structure of the Bohemian Massif and adjacent Variscan belt in central Europe based on profile S01 from the SUDETES 2003 experiment, J. Geophys. Res., 113, B10304, doi:10.1029/2007JB005497, 2008.

Hainzl, S., Fischer, T., and Dahm, T.: Seismicity-based estimation of the driving fluid pressure in the case of swarm activity in Western Bohemia, Geopy. J. Int., 191, 271-281, doi:10.1111/j.1365246X.2012.05610, 2012.

Heuer, B., Geissler, W. H., Kind, R., and Kämpf, H.: Seismic evidence for asthenospheric updoming beneath the western Bohemian Massif, central Europe, Geophys. Res. Lett., 33, L05311, doi:10.1029/2005GL025158, 2006.

Horálek, J. and Fischer, T.: Role of crustal fluids in triggering the West Bohemia/Vogtland earthquake swarms: just what we know (a review), Stud. Geophys. Geod., 52, 455-478, 2008.

Horálek, J. and Š́lený, J.: Source mechanisms of the 2000earthquake swarm in the West Bohemia/Vogtland region (Central Europe), Geophys. J. Int., 194, 979-999, doi:10.1093/gji/ggt138, 2013.

Hrubcová, P. and Geissler, W. H.: The Crust-Mantle Transition and the Moho beneath the Vogtland/West Bohemian Region in the Light of Different Seismic Methods, Stud. Geophys. Geod., 53, 275-294, 2009. 
Hrubcová, P., Środa, P., Špičák, A., Guterch, A., Grad, M., Keller, G. R., Brückl, E., and Thybo, H.: Crustal and uppermost mantle structure of the Bohemian Massif based on CELEBRATION 2000 data, J. Geophys. Res., 110, B11305, doi:10.1029/2004JB003080, 2005.

Hrubcová, P., Vavryčuk, V., Boušková, A., and Horálek, J.: Moho depth determination from waveforms of microearthquakes in the West Bohemia/Vogtland swarm area, J. Geophys. Res., 118, 120137, doi:10.1029/2012JB009360, 2013.

Ibs-von Seht, M., Plenefisch, T., and Klinge, K.: Earthquake swarms in continental rifts - A comparison of selected cases in America, Africa and Europe, Tectonophysics, 452, 66-77, 2008.

Klemt, C.: Seismic imaging of the crustal structure in the central European Variscan orogen by reprocessing of the deep seismic reflection profiles GRANU9501 und GRANU9502, Master thesis, TU Bergakademie Freiberg, 2013.

Knett, J.: Das Erzgebirgische Schwarmbeben zu Hartenberg vom 1. Jänner bis 5. Feber 1824. - Sitzungsber. Dt. Naturwiss.-Med. Verein Böhmen Lotos Prag N.F. 19, 167-191, 1899.

Lees, J. M.: Multiplet analysis at Coso geothermal, B. Seismol. Soc. Am., 88, 1127-1143, 1998.

Lehman, R. M.: Microbial distribution and their potential controlling factors in terrestrial subsurface environments, in: The spatial distribution of microbes in the environment, edited by: Franklin, R. B. and Mills, A. L., Springer, 135-178, 2007.

Matte, P., Maluski, H., Rajlich, P., and Franke, W.: Terrane boundaries in the Bohemian Massif: result of large-scale Variscan shearing, Tectonophysics, 177, 151-170, doi:10.1016/00401951(90)90279-H, 1990.

McNutt, S. R.: Volcano seismology, Annu. Rev. Earth Pl. Sc., 33, 461-491, 2005.

Mogi, K.: Some discussions on aftershocks, foreshocks and earthquake swarms - the fracture of semi-infinite body caused by an inner stress origin and its relation to the earthquake phenomena, Bull. Earthquake Res. Inst., 41, 615-658, 1963.

Mrlina, J., Kämpf, H., Kroner, C., Mingram, J., Stebich, M., Brauer, A., Geissler, W. H., Kallmeyer, J., Matthes, H., and Seidl, M.: Discovery of the first Quaternary maar in the Bohemian Massif, Central Europe, based on combined geophysical and geological surveys, J. Volc. Geoth. Res., 182, 97-112, doi:10.1016/j.jvolgeores.2009.01.027, 2009.

Mullick, N., Buske, S., Shapiro, S., and Wigger, P.: Reflection seismic investigation of the geodynamically active WestBohemia/Vogtland region. Basalt 2013 - Cenozoic Magmatism in Central Europe, Görlitz, 24-28 April, Görlitz/Germany, 2013.

Parkes, R. J., Cragg, B. A., Bale, S. J., Getliff, J. M., Goodman, K., Rochelle, P. A., Fry, J. C., Weightman, A. J., and Harvey, S. M.: Deep bacterial biosphere in Pacific Ocean sediments, Nature, 371, 410-413, 1994.

Parkes, R. J., Cragg, B. A., and Wellsbury, P.: Recent studies on bacterial populations and processes in subseafloor sediments: a review, Hydrogeol. J., 8, 11-28, 2000.

Pedersen, K.: Exploration of deep intraterrestrial microbial life: current perspectives, Federation of European Microbiological Societies Microbiology Letters, 185, 9-16, 2000.

Pitra, P., Burg, J. P., and Guiraud, M.: Late Variscan strike-slip tectonics between the Tepla-Barrandian and Moldanubian terranes (Czech Bohemian Massif): Petrostructural evidence, J. Geol. Soc. London, 156, 1003-1020, 1999.
Prodehl, C., Mueller, S., and Haak, V.: The European Cenozoic Rift System, in: Continental rifts: evolution, structure, tectonics, edited by: Olsen, K. H., Developments in Geotectonics, Elsevier, 133-212, 1995.

Proft, E.: Kammerbühl und Eisenbühl, die Schichtvulkane des Egerer Beckens, Jahrb. Geol. Reichsanstalt Wien, 44, 25-85, 1894.

Schimschal, S.: Seismic imaging of the crustal structure in the Münchberg/Vogtland/Erzgebirge area by reprocessing of the deep seismic reflection profile MVE90, Master thesis, TU Bergakademie Freiberg, 2013.

Schreiber, U., Locker-Grütjen, O., and Mayer, C.: Hypothesis: origin of life in the deep-reaching tectonic faults, Orig. Life Evol. Biosph., 42, 47-54, doi:10.1007/s11084-012-9267-4, 2012.

Seifert, W. and Kämpf, H.: Ba-enrichment in phlogopite of a nephelinite from Bohemia, Eur. J. Mineral., 6, 497-502, 1994.

Tomek, Č., Dvořáková, V., and Vrána, S.: Geological interpretation of the 9HR and 503M seismic profiles in Western Bohemia, in: Geological model of Western Bohemia related to the KTB borehole in Germany, edited by: Vrána, S. and Štědrá, V., J. Geol. Sci. Geology, 47, 43-50, 1997.

Ulrych, J., Dostal, J., Adamovič, J., Jelínek, E., Špaček, P., Hegner, E., and Balogh, K.: Recurrent Cenozoic volcanic activity in the Bohemian Massif (Czech Republic), Lithos, 123, 133-144, 2011.

Vavryčuk, V.: Crustal anisotropy from local observations of shearwave splitting in West Bohemia, Czech Republic, Bull. Seism. Soc. Am., 83, 1420-1441, 1993.

Vavryčuk, V.: Principal earthquakes: Theory and observations from the 2008 West Bohemia swarm, Earth Planet. Sci. Lett., 305, 290-296, doi:10.1016/j.epsl.2011.03.002, 2011.

Vavryčuk, V., Bouchaala, F., and Fischer, T.: High-resolution fault image from accurate locations and focal mechanisms of 2008 swarm earthquakes in West Bohemia, Czech Republic, Tectonophysics, 590, 189-195, doi:10.1016/j.tecto.2013.01.025, 2013.

Vuillemin, A. and Ariztegui, D.: Geomicrobiological investigations in subsaline maar lake sediments over the last 1500 years, Quaternary Sci. Rev., 71, 119-130, doi:10.1016/j.quascirev.2012.04.011, 2013.

Weinlich, F. H., Bräuer, K., Kämpf, H., Strauch, G., Tesař, J., and Weise, S. M.: An active subcontinental mantle volatile system in the western Eger rift, Central Europe: Gas flux, isotopic (He, C, and $\mathrm{N}$ ) and compositional fingerprints, Geochim. Cosmochim. Ac., 63, 3653-3671, 1999.

Whitman, B., Coleman, D. C., and Wiebe, W. J.: Prokaryotes: the unseen majority, P. Natl. Acad. Sci. USA, 95, 6578-6583, 1998.

Wyss, M., Shimazaki, K., and Wiemer, S.: Mapping active magma chambers by b values beneath the off-Ito volcano, Japan, J. Geophys. Res., 102, 20413-20422, doi:10.1029/97JB01074, 1997.

\section{Related web link}

http://egerswarms.icdp-online.org, http://eger.icdp-online.org 